\title{
Chapter 3 \\ Multiple Marginalizations Based on Age: Gendered Ageism and Beyond
}

\author{
Clary Krekula, Pirjo Nikander, and Monika Wilińska
}

\subsection{Introduction}

When Butler introduced the concept of ageism in 1969, it primarily aimed to highlight forms of marginalization and discrimination that older people are exposed to. This was in line with the wider scientific discourse of the time that focused on revealing categorical inequalities as experienced by different social groups based on age, gender, race/ethnicity, and so on. Rooted in social movements, the debate revolved around identity politics with an ambition to expose unique forms of discrimination faced by diverse social groups that were, however, approached from the perspective of a homogeneous collective (Addelson and Potter 1991; Mirza 1997).

As presented in the Chap. 25 by Snellman in this volume (2018), ageism has made a conceptual journey since its inception in the 1960s. One of the hallmarks of that journey was a gradual move from understanding ageism in terms of attitudes only to conceptualizing it as a form of oppression deeply embedded in social structures. In parallel, age is increasingly seen as a socially constructed category that is by no means equivalent to a personal characteristic (Calasanti 2003; Laz 1998; Krekula 2009; Nikander 2009). Age has steadily become recognized as a producer of social division, with a role as a social and identity marker, but also underlining its power in defining social relations, giving rise to institutions and creating inequalities

\footnotetext{
C. Krekula $(\bowtie)$

Karlstad University, Karlstad, Sweden

e-mail: clary.krekula@kau.se

P. Nikander

University of Tampere, Tampere, Finland

e-mail: Pirjo.Nikander@uta.fi

M. Wilińska

Jönköping University, Jönköping, Sweden

e-mail: monika.wilinska@ju.se
}

L. Ayalon, C. Tesch-Römer (eds.), Contemporary Perspectives on Ageism, 
(Gullette 2004; Hockey and James 1993; Krekula 2007; Krekula and Johansson 2016; Nikander 2009). Essentially, this posits age as one of many dimensions of social differentiation processes that cannot be understood in isolation. The understanding of age is therefore becoming further enriched as it is recognized as socially constructed in interaction with other categorizations, such as gender, class, race, and ethnicity (Hockey and James 1993; Krekula 2007; Nikander 2002).

One of the first categories used to complicate the understanding of ageism was gender. The term "gendered ageism" was introduced by Itzin and Phillipson (1993, 1995) in their study of age barriers at work where they focused particularly on gender in both the private and public sector. Since then, gendered ageism has been defined in a range of ways. One recurrent definition describes it as a double jeopardy, where two interacting power systems lead to an increased vulnerability (cf. Barrett and Naiman-Sessions 2016; Handy and Davy 2007; Walker 1998). In gendered ageism, the perspective of double jeopardy emphasizes the dominance of patriarchal norms combined with a preoccupation with youth that results in a faster deterioration of older women's status compared to that of men (Barrett and NaimanSessions 2016).

Any definition of gendered ageism as a phenomenon directed solely against older women is built on delimited categorizations that ascribe them with a presupposed subordinated position. The same is true for definitions of ageism that see it as directed against older people only (see for example Butler 1980; Kalish 1979; Palmore 2001). Both perspectives differ from later research that has shown ageism also as targeting younger people (Duncan and Loretto 2004), and from theoretical work which emphasizes gender as a relational process, and as something which cannot be reduced to women only. Further theoretical problematization of the concept is therefore needed to understand the processes of multiple marginalizations based on age and to see how these affect both men and women of various ages.

In this chapter, we discuss multiple marginalizations based on age by focusing specifically on age and gender as an intersection of power relations. We centre our attention on the concept of gendered ageism that was introduced to spotlight the context-specific dynamics of ageism that women and men alike can be exposed to. The concept is thus placed in a wider context to further problematize the processes which create multiple marginalizations. In this, we draw attention to underlying theoretical assumptions of age-based marginalization and the concept of gendered ageism; we problematize how ageism relates to the current debate on age as socially construed, as a power relation and as marginalization; and we argue that gendered ageism can be understood as a form of doing age. We offer an outline of a research approach that develops the understanding of the processes that can create multiple marginalizations based on age and encourage innovative routes that yield further insight into the complexity of social and gendered inequalities in later life. 


\subsection{From Ageism to Gendered Ageism and Multiple Marginalizations}

In their seminar studies of age barriers at work in the public and private sectors, Itzin and Phillipson $(1993,1995)$ managed to show that ageism does not operate in isolation from other categories, and, alongside others, claimed that the sexualization of women's value in youth was a clear proof of this. They concluded that "gender on its own is an insufficient explanation of the discrimination experienced by women in organisations" (Itzin and Phillipson 1995, p. 91) and claimed that "gendered ageism" formed a central part of organizational cultures. They discovered discrimination in relation to recruitment, career, and pension, and noted that women were defined as ageing at an earlier chronological age, reaching their peak at age 35, while men were considered to reach their peak much later. Their argument indicated that gendered ageism also meant age- and gender-based glass ceilings for women regarding both employment and promotion.

The definition of gendered ageism as a double jeopardy has, with some modification, been applied by other researchers, not least some feminist researchers (e.g., Arber and Ginn 1991; Duncan and Loretto 2004). Researchers have shown that women of all ages, more so than men, experience ageism based on appearance and sexuality in the labour market, among other contexts (Clarke and Griffin 2008; Duncan and Loretto 2004; Granleese and Sayer 2006). Research has also shown, for example, that doctors ask fewer questions and prescribe less medication for coronary heart disease to middle-aged women, which in turn can contribute to inequality in relation to health (Arber et al. 2006), and that female older workers were made invisible in a public inquiry into the older unemployed, due to a discursive struggle for recognition of older male workers as a disadvantaged group in the labour market (Ainsworth 2002).

The concept of gendered ageism as a double jeopardy is also used when pointing to the dynamics of gendered ageism and other categorizations and dimensions, like physical beauty and looks. Here, a so-called triple jeopardy occurs, as appearance has been posited as a further interactive dimension of ageism against women (cf. Granleese and Sayer 2006; Handy and Davy 2007; Jyrkinen 2013; Jyrkinen and McKie 2012). However, in societies that favour health, vitality, and appearance, such requirements might affect older men as well (Hearn 1995). The combined normative forces of healthism (Crawford 1980), lookism, and fitnessism, further supported by ideals of consumerism, means that our future understanding and the scope of gendered ageism continues to unfold.

Despite numerous definitions and continuous discussions on the combined effect of age and gender, the terms double/triple jeopardy remain theoretically underdeveloped and somewhat poorly explored (for a criticism of the concept, see Krekula 2007). For instance, while the dual effect of gender and age is often evidenced by examples concerning women, no substantial data or ambitious theorizing to date exists on whether and how such combined jeopardies affect men, and, if they do, how the dynamics, contexts, and experiences of such ageism might change. Duncan 
and Loretto's (2004) study on ageism in working life showed that a larger number of men than women experienced age discrimination, particularly among the age group 25-44. Consequently, they argued that it would actually be more appropriate to apply the slogan "Never the right age" to men rather than to women. In a similar vein, Thompson (1994) argued that later-life masculinities have been subordinated to the effort to understand middle-aged and younger men's lives, which contribute to gerontophobic masculinity ideals. More recently, work on gendered ageism has mapped the contextual variations and the gender-specific dynamics of people's daily lives to see how interactional contexts shape men's perceptions of ageism in ways that work to provide them with immunity from it (Ojala et al. 2016).

Based on an analysis of an employment tribunal court's final judgment of an accusation of discrimination on the basis of both age and gender, Spedale et al. (2014) argued that ageism has a base in the social construction of an ideology of youthfulness. This ideology is described as having been reproduced through discourses on "brand refreshment and rejuvenation" (p. 1586) and, in that way, obscuring the agency of the more powerful organizational actors while at the same time marginalizing the weaker ones (cf. Clarke and Griffin 2008 and Handy and Davy 2007 on ageism and youthfulness). However, the ideology of youthfulness as a starting point does not suffice to explain marginalization based on age, as it affects younger age groups as well. An increasing number of studies demonstrate that ageism is also directed against children and youth, often discussed through the concepts of adultism (Bell 1995; Ceaser 2014; Flasher 1978; Kennedy 2006) and childism (Pierce and Allen 1975; Young-Bruehl 2012). For instance, entry as well as exit from the labour market can be affected by ageism, the former to a large extent especially targeting youth.

Later shifts in the problematization of both age and ageism resulted not only from changing social realities but also from theoretical developments in understanding inequalities more broadly. Where a focus on homogeneous categories used to exist, contemporary research emphasizes differences within categorizations like age, revealing also their relational nature. For instance, a growing number of studies explore the interaction between age, gender, and class (see McMullin and Cairney 2004; Zajicek et al. 2007), age, gender, and race (Mair 2010), age, gender, and sexuality (Ambjörnsson and Jönsson 2010), and age and masculinity (Bartholomaeus and Tarrant 2016). Reviewing dominant ways of approaching intersectionality and reflecting upon their shortcomings, Walby et al. (2012) proposed that an intersectional perspective encourages a language of inequalities and systems of inequalities. From this perspective, intersectionality stresses the need to understand the powerful alongside the powerless and opens a discourse of mutual shaping while recognizing the flexibility and the unfinished projects of creating differences.

Transferred to debates on ageism, these developments demonstrate that the main problem with the concept, or any other social inequality for that matter, is not oppression organized along the lines of age. Rather, analytic and theoretical work increasingly zoom in on the coexistence of various intersecting forms of oppression that are recreated to produce differencing outcomes and conditions for various groups of people. These challenges are yet to be taken up in the discussions regarding 
ageism. First, as Gullette (2004) vehemently advocated, there needs to be a greater understanding of the prominence of age in the lives and institutions that relate not only to older people but to people of all ages. Second, the relations between people and institutions need to be seen as an interactive whole rather than as flows between static entities (Hancock 2007). Third, instead of presuming a priori defined categories, any intersectional perspective on ageism needs to employ a more empirically driven approach to discover rather than just to test assumptions that are taken for granted (Hancock 2007).

\subsection{The Perspective of Age as Doing}

The perspective of age as doing is grounded in an understanding of age as a socially and culturally constructed category. As such, age does not constitute a role, an identity, or an individual attribute, but is rather an expression of the social context. Researchers have used different concepts to discuss the active and interactional dynamics of age, for example, age-as-accomplishment (Laz 1998), generationing (Alanen 1992), as doing age (Nikander 2002, 2009; Utrata 2011), age relations (Calasanti 2003), and age coding (Krekula 2009). Such interactional perspectives of age offer a move beyond simple understandings of marginalization or ageism as things that are done to one group by members of another. What we begin to see instead is a collaborative social process that involves everyone. This means that ageism, similar to other inequalities, is situationally and interactionally accomplished rather than a natural category (Schwalbe 2008).

Furthermore, to conceive of ageism as actively created in social encounters and processes is to recognize that no one has a predefined role of a victim or an offender. This immediately challenges the widely spread discourse on old age and ageism in which older people are mere victims of ageism. To date, the literature on ageing and inequality typically focusses on things that are perpetrated against old people, while less attention is given to ageist actions by older people themselves. Minichiello et al. (2000) discussed, for example, the concept of interactive ageism to emphasize the diverse ways in which people of different ages respond to and reproduce ageism. Likewise, older people with different life experiences and histories respond to similar oppressive structures differently. What is more, on many occasions, older people themselves are found to convey and maintain ageist attitudes, and to partake in selfinflicted ageism (e.g., Andrews 1999; Hurd 1999; Lund and Engelsrud 2008; Öberg and Tornstam 2001; Wilińska 2012).

Age as formed in and through interaction, negotiation, and on-going discursive processes involves everyone at different levels. Fineman (2011) described this with the metaphor "the social game we play with age" and argued that age as an organizing principle is powerful because it is seen as a neutral affiliation and because the organization thus receives an objective character. In a similar vein, Nikander (2002) claimed that "the theoretical and analytic myopia of much lifespan and ageing research has, in practice, meant overlooking the interactional processes whereby 
age and its meanings are accomplished" (p. 29). The study of age from an interactional perspective thus means examining the nuances and situationally or institutionally processual dynamics of age rather than the category itself. How does age become relevant? How is it done, by whom, and to what ends? When analysing the persistence of the hierarchical gender system, Ridgeway and Correll (2004) proposed that in addition to considering gender norms and beliefs, it is crucial to consider social relational contexts, which they define as "the arenas where these beliefs or rules are in play" (p. 511). This framework can be applied to age to disentangle the variety of ways in which age enters or is actively brought into people's everyday thinking and discourse and institutional contexts, and the ways it produces age orders that organize societies (Twigg 2004).

Observing the encounters between art gallery workers and visitors at the ticket office, Llewellyn (2015) demonstrated the creative ways in which the parties collaboratively do age while engaging in the process of purchasing and selling agegrouped and age-priced entry tickets. Here, the organizational encounter was structured according to the age of the visitors. Some visitors voluntarily announced membership in an age category to receive an age concession. At other times, gallery workers stepped in and actively offered the concession based on their professional ability to interpret visual age cues. An opposite relation was observed in a study of a non-governmental organization working with social programmess addressing older people (Wilińska and Henning 2011). The organization first used socially available images of age to construct an intervention program, and then looked for people who would fit into a very precise definition of an older person. The organizational objectives were therefore reliant on the process of fitting real people into age categories; age was used as resource enabling the organization to govern the participants.

Age as a cultural and social construct comes with an easily accessible and readyto-use arsenal of culture-specific beliefs and norms (see also Tilly 1998, 2003). These are construed around opposing poles: "young," the desired age characterized by beauty, vitality, and strength; and "old," the feared age associated with decline, disease, and weakness. In this construct, age is a cultural resource that, like any other category, helps us make sense of reality, but also limits our way of thinking (Juhila 2004; Ojala et al. 2016). For example, when 55+ members of the University of the Third Age (U3A) reject the idea of old age, they reject the socio-cultural construct that has also very strong moral underpinnings (Wilińska 2012). The rejection becomes an act of protecting one's sense of self-esteem and self-identity.

The same goals of protecting one's sense of self-esteem and self-identity can also be achieved via bodily practices. For instance, a study by Ward and Holland (2011) following older women and their hairdressing practices demonstrated that older women who dyed their hair were not interested in just any type of beauty. Instead, they were interested in non-old standards of beauty. Similarly, when Twigg (2012) discussed the dressing practices of older women, she demonstrated the negotiations and struggles that go into deciding not only what to wear but also where to purchase the clothes. As Krekula (2009) pointed out, different outfits and shopping spots are age coded to indicate those that are more or less appropriate for certain groups of 
women. Regardless of the outcome of such negations, age stands out as a cultural and actively (re)produced resource that facilitates the process of even mundane decision making.

As a chronologically ordered category, age, in other words, clearly allows us to situationally mark and index cultural lifespan norms, preferences, and activities (Nikander 2002). Krekula and Johansson (2016) have noted that there are different aspects of the meaning-creating contexts where age is done. They argue that, even though these are not separate from each other, it can be fruitful to distinguish between, for example, age as a norm, age as a (discursive) resource, and age as marginalization. These different types of doing relate to ageism in different ways, and the doing of age is intimately connected with age as a power relation.

Regardless of the concepts applied, age is thus understood as a kind of political and discursive location. Thus, the perspective of age as doing is only one of several steps that need to be taken in order to have a broader and more dynamic understanding of ageism. Each act of doing, negotiating, and interacting is deeply situated in power structures that are constantly recreated. Age must therefore be understood as an important power structure that has a key role in organizing society, informing groups' identities and their access to power, and intersecting with other power relations (Calasanti and Slevin 2006; Calasanti et al. 2006; Fineman 2011; Krekula 2009). It is only via such conceptualization of age that we come closer to understanding the diversity and complexity of ageing, and by extension, ageism (McMullin 2000).

\subsection{The Perspective of Age as a Power Relation}

Power is not something that one has while others do not; power is a productive capacity emerging in and producing social relations (Foucault 1997). Taking into account the diverse theoretical definitions of power, we take it to refer to the "capacity to make things happen, but exactly what can be made to happen always depends on the context in which resources we possess are or are not usable" (Schwalbe 2008, p. 201). To re-emphasize, it is the situational context that makes some resources more usable than others, and that determines the ways in which those resources can be used.

Three dimensions of power are particularly relevant when seeking to understand ageism: categorical inequality, the normality which appears in (un)marked age, and the structuring via temporality which exists for example in institutionalized life courses and various temporal codes (Krekula and Johansson 2016).

Using the concept "categorical inequality," Tilly (1998, 2003) discusses how "durable inequalities" arise in categorical pairs that are transferred across interactions and contexts, thus (re)producing the system of inequalities organized along the lines of age, gender, race, religion, sexuality, and (dis)ability. In this, the meaning of age to the system of inequality cannot be fully comprehended without understanding the dynamic existing between "old" and "young" age. These two opposing 
categories not only delineate the discursive possibilities, but also indicate the system of values, activities, and norms. To be young is to be active and full of life; to be old is to be passive and void of life. The categorization is, thus, held as the fundamental cause behind inequality and marginalization (see also Bodily 1994), or as expressed with the concept of age coding: these are practices of distinction that are based on and preserve representations of actions, phenomena, and characteristics as associated with and applicable to demarcated ages (Krekula 2009).

The strength in these processes is that they facilitate the transfer of joint notions, practices, and interpersonal relations between different contexts and, by doing so, enable the reproduction of old routines in new contexts. All in all, this perspective points to the fact that inequality is not something done by some people to others, but rather it is a process involving various actors, who do not necessarily reproduce inequality in order to perpetuate harm, but rather to accomplish different goals and objectives. Marginalization based on age is, thus, created in the practices where age is done; it is a form of age doing. In the words of Tilly $(1998,2003)$, inequality is created when people try to solve other organizational problems by applying categorical inequality to divide valued resources. The availability of existing categorization scripts makes the whole process very easy and accessible to everyone who shares the same socio-cultural context. This is also what makes the process very durable and dangerous.

Through categorization, we do perpetuate marginalization. As Schwalbe (2008) contends, the power of small things contributing to the process of inequality is underestimated. This is particularly the case when those small things we do are conceived of as natural or when categorical notions are discussed in terms of normality. Krekula and Johansson (2016) use the the concept pair marked/unmarked age to problematize this type of normality based on age. They argue that marginalization of demarcating age groups is created in the processes where some ages are construed as an unproblematized-“unmarked"-norm, by means of, for example, prefixes and derogatory names which construct one side of a binary categorization as epistemologically unproblematic. When age is done as an age hierarchy, discursively and materially, the unmarked age is both the basis for the doing and the main beneficiary of it. The unmarked age makes up the norm to which other ages relate (Brekhus 1998).

The way normality is shaped and which age groups appear as an unproblematized norm and which are seen as divergent varies in different contexts and situations. For example, Krekula's studies on discrimination and age relations in work organizations show how age normality varies among different work organizations. While employees just under the age of 40 are considered to be too old by the telemarketing industry, they can also be seen as too young to gain status and prestigious assignments within parts of the academic world (Krekula 2011) or regarded as being of the best age to be a firefighter (Krekula 2012). It is therefore essential to precisely focus on the unspoken norm organizing a given context. Importantly, the unspoken/the norm is context-bound, meaning that, once revealed, the same unmarked category cannot be simply applied to different contexts. For example, 
while being 50 is often considered to be "far too old" to become a parent, the same age is regarded as "far too young" to retire (Wilińska and Cedersund 2010).

A third relevant power approach puts emphasis on normativity in relation to temporality: the complex and dynamic relations between the past, the present, and the future (West-Pavlov 2013). This type of power-norma-/temporality (Krekula and Johansson 2016) - is practised through notions of how life ought to be lived and through norms of what is considered a natural consequence and time for different phases in life such as education, long-term relationships, having a family, and retirement. Even though this power perspective has been lifted within several different disciplines in recent years, for example in social and cultural studies (see Ahmed 2007) and queer studies (see Freeman 2010; Halberstam 2005; Riach et al. 2014), the life course perspective has been the most prominent perspective so far.

In his seminal definition of the life course, Elder (1994) describes it as "pathways through the age-differentiated life span, to social patterns in the timing, duration, spacing and order of events" (p. 21). Life course as socially constructed is seen as a dynamic process in which structured pathways interrelate with individual life trajectories. Those structural pathways are bounded by institutions that create a frame for our lives.

One of the most influential theories concerning the patterning of the life course as movement through a sequence of positions is a model of the institutionalization of the life course (Kohli 1986, 1988). This widely used and accepted theory emphasizes life-time temporalization as one of the core structural features of the life course. It sees chronological age as having become the basic criterion for a standardized "normative life course," and focusses on the institutional patterns that shape life course movement through a temporal tripartite order of periods of preparation, activity, and retirement (Kohli 1986, p. 272). The institutionalized life course model provides a general macrosociological frame for understanding how specific patterns of rules constituting the life course operate and process people through social structure, and how collective institutional transitions and expectations shape individual actions and people's biographical perspectives. It can therefore be seen as a power structure - a temporal regime-both in terms of division of resources and opportunities, and as a type of disciplinary element to enforce norm compliance.

The degree to which a unified model of the historical institutionalization of the life course still captures the increasing complexity, heterogeneity, and social differentiation across life can easily be thrown into question. Indeed, both class and gender (Formosa and Higgs 2013; O'Rand and Henretta 1999) as major potential sources of social inequality and marginalization clearly challenge life course patterns and typical (male) trajectories. Bringing gender and gender specific economic life course dynamics and pluralities into the picture clearly complicates any formerly clear-cut view on life course inequality and ageism. 


\subsection{Gendered Ageism as Doing}

Understanding age as doing, and thus also as a power relation, sheds new light on the concept of ageism. Not only does it illustrate the complexity of ageism, but also emphasizes the need to approach marginalization based on age from the perspective of multiplicity. This brings us back to the discussion on gendered ageism and the need to further problematize it theoretically.

We argue that gendered ageism can be understood as a dynamic social positioning practice. This is in contrast to the common approach to gendered ageism that conceives it in terms of stereotypes, prejudices, and discrimination. We draw on contemporary research on age and other social positions that put emphasis on categorizations and the relations between them as created through practices, processes, and everyday interactional doings where one applies notions of difference between age groups. Jyrkinen (2013) gives an example of the elements of such an approach to gendered ageism. Starting from a position that ageism is a question of discriminating practices (for an overview of this perspective, see, e.g., Heikkinen and Krekula 2008; Wilkinson and Ferraro 2002), Jyrkinen argued that gendered ageism refers to discriminatory actions, whether intentional or non-intentional, that are based on the intersection of gender and age. She also contends that gendered ageism is not limited to relations between men and women, but also manifests among women as well as among men.

In a similar vein, we propose that gendered ageism is not only based on notions that age and gender groups are different, but also on notions that phenomena, situations, and spaces are gendered and age coded (Krekula 2009). Importantly, such coding takes place within the context of other structures (e.g., class, ethnicity) that actively delineate the possible repertoire of resources and practices used to define certain situations and their actors. For example, the idea of Marks and Spencer (a company that sells clothing among other things) as a store for older women (Twigg 2012) is also intertwined with structures of social class and ethnicity.

We understand gendered ageism as consisting of differentiating practices which put demarcated age and gender groups in a marginalized position, or, expressed differently, practices which give age-based meaning to bodies. In other words, specific age and gender codings result in the subordination of and in unequal division of resources for the demarcated group. Implied in this is the fact that the perspective of power has not so far been explicitly applied in work on the concept of gendered ageism. However, the presence of power relations in assumptions about gendered ageism appears in studies which emphasize counter-power, or strategies against ageism. One example is Barrett and Naiman-Sessions' (2016) focus on how the simulation of girlhood by the so-called Red Hat Society, in the forms of adopting children's social roles, dressing up, and playing, constitutes a performative act that resists gendered ageism by increasing ageing women's visibility and asserting their right to leisure. At the same time, they argue, it can be seen as resonance with a dominant cultural metaphor for old age as a "second childhood" and therefore not 
only provides opportunities for resistance to gendered ageism but also contributes to its entrenchment.

Similar strategies and counter-power can be seen in Clarke and Griffin's (2008) study on how women up to the age of 70 used beauty work to respond to gendered ageism. The practices they discussed-dressing and beauty—can be seen as an attempt to broaden the room for manoeuvring by challenging perceived age coding (Krekula 2009; Nikander 2008), and therefore can be interpreted as strategies against categorical inequality. This is further exemplified by a study of active, female members of the University of the Third Age. At the outset of ageist structures that exclude older people from social and public life, older women actively turn to different images of womanhood to create a more positive environment for themselves. Effectively, they repress oppressive age identities to fully embrace their various gender identities, such as wife, mother, or girlfriend (Wilińska 2016). Turning to the feminine appears to be an enabling strategy among older women that reduces the impact of ageism that is innately gendered.

Gendered ageism as a practice of inequality is deeply embedded in institutions. Age as a category that defines social relations gives rise to various age-based institutions. One of these is retirement and the pension system. The extant literature examining these two major age-based institutions provides a wealth of examples of how the institutionalized life course contributes to the marginalization and discrimination that, engaging with age, engages also with gender. For example, recent developments within the pension system schemes that promote individualization and privatization of pensions are found to exacerbate gender inequality (Leitner 2001), where the diverse life courses and work histories of men and women have their immediate result in a considerable gender pension gap (Foster and Smetherham 2013; Frericks et al. 2007, 2009; Price 2006). Therefore, not without a reason, Hartmann and English (2009) stated that financial security while on pension is of particular importance to women. The institution of retirement as we know it is a men's concept (Calasanti 1993, 2002) and within that context it is not surprising that unquestioned heteropatriarchal norms (Grady 2015) are overlooked in social policies as a gender-neutral approach.

We also emphasize the relational character of gendered ageism, meaning that its constitutive practices and outcomes vary from situation to situation. This may refer to a range of language and bodily practices that only when put in context gain their ageist meaning. For example, the perception of hair dying as a potentially ageist practice changes its meaning not only depending on how old the person doing it is (compare a 20-year-old woman with a 60-year-old woman), but also what the purpose of doing it is (e.g., covering grey hair versus dressing up for a Halloween party). Similarly, it is within the limits of certain situations that we observe the ways in which gendered ageism affects various groups. This interactive approach to gendered ageism means that we need to remain open to the empirical results revealing concrete forms of marginalization as directed towards different groups of men and women (Ojala et al. 2016). 
Further, approaching gendered ageism through the perspective of ongoing dynamics and processes means recognizing that the construction and reproduction of various age and gender categories takes place in a range of contexts serving different purposes and involving discursive and bodily practices. The doing of age as a power relation is an embodied practice in a sense that age and ageist practices always refer to concrete bodies that are assessed via the perspective of age (Laws 1995). Laz (2003) adds to that, emphasizing the mutually constitutive relation between age and embodiment that cannot be separated. In this, bodies are often the key markers of age at large. Gendered ageism as a concept cannot therefore be reserved for certain groups of people, and the understanding of embodied age opens new ways for examining this phenomenon. For example, a reflection upon media representations of successful ageing images (Calasanti and King 2005) reveals the ways in which bodies of older men are highly sexualized and described based on gendered age norms. Thus, men are not immune to ageism (Duncan and Loretto 2004; Ojala et al. 2016), but the outcomes of gendered ageism on the lives of older men and women are different, as Sandberg's (2013) study on intimate relationships demonstrates.

\subsection{Conclusions}

Starting out from a discussion about the concept of gendered ageism, this chapter problematizes and further develops the phenomenon of multiple marginalizations based on age. Our discussion is inspired by critical age research, a field which emphasizes age as organizing, doing, and as a power relation, and which argues for analyses based on wide age spans, that is, those that do not simply focus on demarcating age categorizations (Krekula and Johansson 2016). This proposition echoes an understanding of different social divisions as having varying organizing logics (e.g., Phoenix and Pattenama 2006; Yuval-Davis 2006).

In this chapter, we placed gendered ageism in a wider context and subsequently examined two interconnected practices: age as doing and age as a power relation. We introduced the concept as a socially constructed relational and differentiating practice, which places specific age groups in marginalized positions with unequal division of resources. From the social constructionist perspective, meanings of age are upheld and/or challenged in everyday interactions, and gender, like other intersectional categorizations, becomes enmeshed with age in everyday encounters. From this perspective, gender as an interactionally constructed facet of ageism can be understood as something which sheds light on age, and, in a similar vein, on practices that construe age as a position of marginalization. This understanding can also, as we have discussed here, be generally applied to multiple marginalization based on age. Below we outline the key starting points for further research on gendered ageism and multiple marginalization. 
One of the most important insights following from our definition of gendered ageism is that research into this phenomenon (and other marginalizations based on age) cannot easily be related to chronological age only. For example, studies highlighting appearance as central to the discrimination of older women (Clarke and Griffin 2008; Handy and Davy 2007) indicate that problematizations of gendered ageism cannot only be based on chronological age, but also need to include how these markers are used and how they create ageism. This brings us to the importance of ideas such as lifetime chronological order and temporal schemes, norms, and imperatives as key conditions affecting the organizational lives of both men and women. The concept of gendered ageism clearly calls for studies that take to heart the temporal processual aspects that may help to further dismantle typical life course patterns. These temporal aspects and dynamics, taken together and explored as mutually intertwined, may open up new venues for the theorizing of multiple, intersectional marginalizations. Viewed in this manner, age, gender, sexuality, and class as temporal practices (see Ahmed 2007) may be approached in ways that go beyond simple understandings built on additive or mutually reinforcing relationships characterized by former notions of double or triple jeopardy.

Methodologically, this draws us towards everyday life and interactional approaches to the study of social life, or as Sztompka (2008) calls it, the sociology of existence that aims to capture social life as it unfolds. By aiming to grasp "the happening of the social world" (Lury and Wakeford 2012, p. 2; see also Pink 2012), we propose to focus on the processes and practices that in turn are contingent upon the engagement with the concepts of time and place.

\section{References}

Addelson, K. P., \& Potter, E. (1991). Making knowledge. In J. E. Hartman \& E. Messer-Davidow (Eds.), (En)gendering knowledge. Feminists in academe (pp. 259-277). Knoxville: The University of Tennessee Press.

Ahmed, S. (2007). A phenomenology of whiteness. Feminist Theory, 8(2), 149-168. https://doi. org/10.1177/1464700107078139

Ainsworth, S. (2002). The 'feminine advantage': A discursive analysis of the invisibility of older women workers. Gender, Work \& Organization, 9(5), 579-601. https://doi. org/10.1111/1468-0432.00176

Alanen, L. (1992). Modern childhood? Exploring the 'child question' in sociology. Institute for educational research. (Publication series A. Research reports 50). Jyväskylä: University of Jyväskylä.

Ambjornsson, F., \& Jönsson, M. (2010). Inledning [Introduction]. In F. Ambjornsson \& M. Jönsson (Eds.), Livslinjer. Berättelser om ålder, genus och sexualitet [Lifelines. Stories about age, gender and sexuality] (pp. 7-21). Gothenburg: Makadam.

Andrews, M. (1999). The seductiveness of agelessness. Ageing and Society, 19, 301. https://doi. org/10.1017/S0144686X99007369-318

Arber, S., \& Ginn, J. (1991). Gender and later life: A sociological analysis of resources and constraints. London: Sage Publications. 
Arber, S., McKinlay, J., Adams, A., Marceau, L., Link, C., \& O'Donnell, A. (2006). Patient characteristics and inequalities in Doctors' diagnostic and management strategies relating to CHD: A video-simulation experiment. Social Science \& Medicine, 62(1), 103-115.

Barrett, A. E., \& Naiman-Sessions, M. (2016). 'It's our turn to play': Performance of girlhood as a collective response to gendered ageism. Ageing and Society, 36(4), 764-784. https://doi. org/10.1017/S0144686X15000021

Bartholomaeus, C., \& Tarrant, A. (2016). Masculinities at the margins of "middle adulthood": What a consideration of young age and old age offers masculinities theorizing. Men and Masculinities, 19(4), 351-369. https://doi.org/10.1177/1097184X15588592

Bell, J. (1995). Understanding adultism: A major obstacle to developing positive youth-adult relationships. Somerville: YouthBuild.

Bodily, C. L. (1994). Ageism and the deployments of 'age'. In T. R. Sarbin \& J. I. Kitsuse (Eds.), Constructing the social (pp. 174-194). London: Sage.

Brekhus, W. (1998). A sociology of the unmarked: Redirecting our focus. Sociological Theory, 16(1), 34-51.

Butler, R. N. (1980). Ageism: A foreword. Journal of Social Issues, 36(2), 8-11.

Calasanti, T. M. (1993). Bringing in diversity: Toward an inclusive theory of retirement. Journal of Aging Studies, 7(2), 133-150. https://doi.org/10.1016/0890-4065(93)90030-N

Calasanti, T. (2002). Work and retirement in the 21 st century: Integrating issues of diversity and globalization. Ageing International, 27(3), 3-20. https://doi.org/10.1007/s12126-003-1000-1

Calasanti, T. (2003). Theorizing age relations. In S. Biggs, A. Lowenstein, \& J. Hendricks (Eds.), The need for theory: Critical approaches to social gerontology (pp. 199-218). Amityville: Baywood.

Calasanti, T. M., \& King, N. (2005). Firming the floppy penis. Age, class and gender relations in the lives of old men. Men and Masculinities, 8(1), 3-23. https://doi.org/10.1177/10971 $84 X 04268799$

Calasanti, T. M., \& Slevin, K. F. (2006). Introduction. Age matters. In T. M. Calasanti \& K. F. Slevin (Eds.), Age matters. Realigning feminist thinking (pp. 1-17). London: Routledge.

Calasanti, T. M., Slevin, K., \& King, N. (2006). Ageism and feminism: From "et cetera" to center. NWSA Journal, 18(1), 13-30. https://doi.org/10.2979/NWS.2006.18.1.13

Ceaser, D. (2014). Unlearning adultism at green shoots: A reflexive ethnographic analysis of age inequality within an environmental education programme. Ethnography and Education, 9, 167-181. https://doi.org/10.1080/17457823.2013.841083

Clarke, L. H., \& Griffin, M. (2008). Visible and invisible ageing: Beauty work as a response to ageism. Ageing and Society, 28(05), 653-674. https://doi.org/10.1017/S0144686X07007003

Crawford, R. (1980). Healthism and the medicalization of everyday life. International Journal of Health Services, 10(3), 356-388. https://doi.org/10.2190/3H2H-3XJN-3KAY-G9NY

Duncan, C., \& Loretto, W. (2004). Never the right age? Gender and age-based discrimination in employment. Gender, Work \& Organization, 11(1), 95-115. https://doi. org/10.1111/j.1468-0432.2004.00222.x

Elder, G. H. (1994). Time, human agency, and social change: Perspectives on the life course. Social Psychology Quarterly, 57(1), 4-15.

Fineman, S. (2011). Organizing age. Oxford: Oxford University Press.

Flasher, J. (1978). Adultism. Adolescence, 13(51), 517-523.

Formosa, M., \& Higgs, P. (2013). Social class in later life. In Power, identity and lifestyle. Bristol: Policy Press.

Foster, L., \& Smetherham, J. (2013). Gender and pensions: An analysis of factors affecting Women's private pension scheme membership in the United Kingdom. Journal of Aging \& Social Policy, 25(3), 197-217. https://doi.org/10.1080/08959420.2013.791783

Foucault, M. (1997). "Society must be defended." Lectures at the Collège de France 1975-76. New York: Picador. 
Freeman, E. (2010). Time binds: Queer temporalities, queer histories. Durham: Duke University Press.

Frericks, P., Maier, R., \& De Graaf, W. (2007). European pension reforms: Individualization, privatization and gender pension gaps. Social Politics: International Studies in Gender, State \& Society, 14(2), 212-237. https://doi.org/10.1093/sp/jxm008

Frericks, P., Knijn, T., \& Maier, R. (2009). Pension reforms, working patterns and gender pension gaps in Europe. Gender, Work \& Organization, 16(6), 710-730. https://doi. org/10.1111/j.1468-0432.2009.00457.x

Grady, J. (2015). Gendering Pensions: Making Women Visible. Gender, Work \& Organization, 22(5), 445-458. https://doi.org/10.1111/gwao.12096

Granleese, J., \& Sayer, G. (2006). Gendered ageism and "lookism": A triple jeopardy for female academics. Women in Management Review, 21(6), 500-517. https://doi. org/10.1108/09649420610683480

Gullette, M. M. (2004). Aged by culture. Chicago: The University of Chicago Press.

Halberstam, J. (2005). In a queer time and place. Transgender bodies, subcultural lives. New York: New York University Press.

Hancock, A. M. (2007). When multiplication doesn't equal quick addition: Examining intersectionality as a research paradigm. Perspectives on Politics, 5(01), 63-79. https://doi.org/10.1017/ S1537592707070065

Handy, J., \& Davy, D. D. (2007). Gendered ageism: Older women's experiences of employment agency practices. Asia Pacific Journal of Human Resources, 1, 85-99. https://doi. org/10.1177/1038411107073606

Hartmann, H., \& English, A. (2009). Older Women's retirement security: A primer. Journal of Women, Politics \& Policy, 30(2-3), 109-140. https://doi.org/10.1080/15544770902901932

Hearn, J. (1995). Imaging the aging of men. In M. Featherstone \& A. Wernick (Eds.), Images of aging: Cultural representations of later life (pp. 97-115). London: Routledge.

Heikkinen, S., \& Krekula, C. (2008). Ålderism—ett fruktbart begrepp?/Ageism-A useful concept? Sociologisk Forskning, 45, 18-34.

Hockey, J., \& James, A. (1993). Growing up and growing old. Ageing and dependency in the life course. London: Sage.

Hurd, L. C. (1999). We're not old!': Older Women's negotiation of aging and oldness. Journal of Aging Studies, 13(4), 419-439. https://doi.org/10.1016/S0890-065(99)00019-5

Itzin, C., \& Phillipson, C. (1993). Age barriers at work. London: METRA.

Itzin, C., \& Phillipson, C. (1995). Gendered ageism: A double jeopardy for women in organisations. In C. Itzin \& C. Phillipson (Eds.), Gender, culture and organisational change. Putting theory into practice (pp. 84-94). London: Routledge.

Juhila, K. (2004). Talking back to stigmatised identities: Negotiation of culturally dominant categories in the interviews with shelter residents. Qualitative Social Work, 3(3), 259-275. https:// doi.org/10.1177/1473325004045665

Jyrkinen, M. (2013). Women managers, careers and gendered ageism. Scandinavian Journal of Management, 30(2), 175-185. https://doi.org/10.1016/j.scaman.2013.07.002

Jyrkinen, M., \& McKie, L. (2012). Gender, age and ageism: Experiences of women managers in Finland and Scotland. Work, Employment and Society, 26(1), 61-77. https://doi. org/10.1177/0950017011426313

Kalish, R. A. (1979). The new ageism and the failure models: A polemic. The Gerontologist, 19(4), 398-402. https://doi.org/10.1093/geront/19.4.398

Kennedy, D. (2006). The well of being: Childhood, subjectivity, and education. New York: State University of New York.

Kohli, M. (1986). The world we forgot: A historical review of the life course. In W. Marshall (Ed.), Later life: The social psychology of ageing (pp. 271-303). Beverly Hills: Sage.

Kohli, M. (1988). Ageing as a challenge for sociological theory. Ageing and Society, 8, 367-394. https://doi.org/10.1017/S0144686X00007169 
Krekula, C. (2007). The intersection of age and gender: Reworking gender theory and social gerontology. Current Sociology, 55(2), 155-171. https://doi.org/10.1177/0011392107073299

Krekula, C. (2009). Age coding: On age-based practices of distinction. International Journal of Ageing and Later Life, 4(2), 7-31. https://doi.org/10.3384/ijal.1652-8670.09427

Krekula, C. (2011). Åldersdiskriminering $i$ svenskt arbetsliv. Om ålderskodningar och myter som skapar ojämlikhet [Age discrimination in Swedish working life. On age codings and myths that create inequality]. Official report from the Equality Ombudsman. http://www.do.se/ Documents/rapporter/aldersdiskriminering\%20i\%20arbetslivet.pdf

Krekula, C. (2012). Attityder till fysisk styrka: Om kvinnor, äldre brandmän och självupplevda begränsningar [Attitudes to physical strength: On women, older firefighters and self-experienced limitations]. In L.-G. Engström, L. Jakobsen, \& C. Krekula (Eds.), Jämställdhet, mångfald och svenska räddningstjänster. Om föreställningar och förändringsviljor [Gender equality, diversity and Swedish rescue services. On notions and willingness to change] (pp. 71-80). Karlstad: Karlstad University Press.

Krekula, C. \& Johansson, B. (Eds.). (2016). Inledning [Introduction]. In C. Krekula \& B. Johansson (Eds.), Introduktion till kritiska åldersstudier [Introduction to critical age studies]. Malmö: Studentlitteratur.

Laws, G. (1995). Understanding ageism: Lessons from feminism and postmodernism. The Gerontologist, 35(1), 112-118. https://doi.org/10.1093/geront/35.1.112

Laz, C. (1998). Act your age. Sociological Forum, 13(1), 85-113.

Laz, C. (2003). Age embodied. Journal of Aging Studies, 17, 503-519. https://doi.org/10.1016/ S0890-4065(03)00066-5

Leitner, S. (2001). Sex and gender discrimination within EU pension systems. Journal of European Social Policy, 11(2), 99-115. https://doi.org/10.1177/095892870101100201

Llewellyn, N. (2015). 'He probably thought we were students': Age norms and the exercise of visual judgement in service work. Organization Studies, 36(2), 153-173. https://doi. org/10.1177/0170840614546151

Lund, A., \& Engelsrud, G. H. (2008). 'I am not that old': Inter-personal experiences of thriving and threats at a senior centre. Ageing and Society, 28(05), 675-692. https://doi.org/10.1017/ S0144686X07006988

Lury, C., \& Wakeford, N. (2012). Introduction: A perpetual inventory. In C. Lury \& N. Wakeford (Eds.), Inventive methods: The happening of the social (pp. 1-24). London: Routledge.

Mair, C. A. (2010). Social ties and depression: An intersectional examination of black and white community-dwelling older adults. Journal of Applied Gerontology, 29(6), 667-696. https://doi. org/10.1177/0733464809350167

McMullin, J. A. (2000). Diversity and the state of sociological aging theory. The Gerontologist, 40(5), 517-530. https://doi.org/10.1093/geront/40.5.517

McMullin, J. A., \& Cairney, J. (2004). Self-esteem and the intersection of age, class, and gender. Journal of Aging Studies, 18, 75-90. https://doi.org/10.1016/j.jaging.2003.09.006

Minichiello, V., Browne, J., \& Kendig, H. (2000). Perceptions and consequences of ageism: Views of older people. Ageing \& Society, 20, 253-278. https://doi.org/10.1017/S0144686X99007710

Mirza, H. S. (1997). Mapping a genealogy of Black British feminism. In H. S. Mirza (Ed.), Black British feminism. A reader (pp. 1-28). London: Routledge.

Nikander, P. (2002). Age in action: Membership work and stage of life categories in talk. Helsinki: Finnish Academy of Science and Letters.

Nikander, P. (2008). Constructionism and discourse analysis. In J. A. Holstein \& J. F. Gubrium (Eds.), Handbook of constructionist research (pp. 413-428). New York: Guilford Press.

Nikander, P. (2009). Doing change and continuity. Age identity and the micro-macro divide. Ageing \& Society, 29, 863-881. https://doi.org/10.1017/S0144686X09008873

O'Rand, A. M., \& Henretta, J. C. (1999). Age and inequality. Diverse pathways through later life. Boulder: Westview Press. 
Öberg, P., \& Tornstam, L. (2001). Youthfulness and fitness. Identity ideas for all ages? Journal of Aging and Identity, 6(1), 15-29.

Ojala, H., Pietilä, I., \& Nikander, P. (2016). Immune to ageism? Men's perceptions of age-based discrimination in everyday contexts. Journal of Aging Studies, 39, 44-53.

Palmore, E. B. (2001). The ageism survey: First findings. The Gerontologist, 41(5), 572-575. https://doi.org/10.1093/geront/41.5.572

Phoenix, A., \& Pattemana, P. (2006). Intersectionality. Editorial. European Journal of Women's Studies, 13(3), 187-192.

Pierce, C. M., \& Allen, G. B. (1975). Childism. Psychiatric Annals, 5(7), 15-24.

Pink, S. (2012). Situating everyday life: Practices and places. London: SAGE.

Price, D. (2006). Gender and generational continuity breadwinners, caregivers and pension provision in the UK. International Journal of Ageing and Later Life, 1(2), 31-66. https://doi. org/10.3384/ijal.1652-8670.061231

Riach, K., Rumens, N., \& Tyler, M. (2014). Un/doing chrononormativity: Negotiating ageing, gender and sexuality in organizational life. Organization Studies, 35(11), 1677-1698. https:// doi.org/10.1177/0170840614550731

Ridgeway, C. L., \& Correll, S. J. (2004). Unpacking the gender system: A theoretical perspective on gender beliefs and social relations. Gender \& Society, 18(4), 510-531. https://doi. org $/ 10.1177 / 0891243204265269$

Sandberg, L. (2013). Just feeling a naked body close to you: Men, sexuality and intimacy in later life. Sexualities, 16(3-4), 261-282.

Schwalbe, M. (2008). Rigging the game. How inequality is reproduced in everyday life. New York: Oxford University Press.

Snellman, F. (2018). Normative, empiricist, and interpretive considerations in the ageism research process. In L. Ayalon \& C. Tesch-Römer (Eds.), Contemporary perspectives on ageism: Vol. 19. International perspectives on aging (pp. 407-422). Berlin: Springer.

Spedale, S., Coupland, C., \& Tempest, S. (2014). Gendered ageism and organizational routines at work: The case of day-parting in television broadcasting. Organization Studies, 35(11), 15851604. https://doi.org/10.1177/0170840614550733

Sztompka, P. (2008). The focus on everyday life: A new turn in sociology. European Review, 16(1), 23-37. https://doi.org/10.1017/S1062798708000045

Thompson, E. H. (1994). Older men as invisible men. In E. Thompson (Ed.), Older men's lives (pp. 1-21). Thousand Oaks: Sage.

Tilly, C. (1998). Durable inequality. Berkely/Los Angeles: University of California Press.

Tilly, C. (2003). Changing forms of inequality. Sociological Theory, 21(1), 31-36. https://doi. org/10.1111/1467-9558.00173

Twigg, J. (2004). The body, gender, and age: Feminist insights in social gerontology. Journal of Aging Studies, 18(1), 59-73. https://doi.org/10.1016/j.jaging.2003.09.001

Twigg, J. (2012). Fashion and age: Dress, the body later life. London: Bloomsbury.

Utrata, J. (2011). Youth privilege doing age and gender in Russia's single-mother families. Gender \& Society, 25(5), 616-641.

Walby, S., Armstrong, J., \& Strid, S. (2012). Intersectionality: Multiple inequalities in social theory. Sociology, 46(2), 224-240. https://doi.org/10.1177/0038038511416164

Walker, A. (1998). Age and employment. Australasian Journal on Ageing, 17(1), 99-103. https:// doi.org/10.1111/j.1741-6612.1998.tb00876.x

Ward, R., \& Holland, C. (2011). 'If I look old, I will be treated old': Hair and later-life image dilemmas. Ageing \& Society, 21, 288-307. https://doi.org/10.1017/S0144686X10000863

West-Pavlov, R. (2013). Temporalities. New York: Routledge.

Wilińska, M. (2012). Is there a place for an ageing subject? Stories of ageing at the University of the Third Age in Poland. Sociology, 46(2), 290-305. https://doi.org/10.1177/0038038511419179

Wilińska, M. (2016). Proud to be a woman: Old age, womanhood and emotions. Journal of Women and Aging. https://doi.org/10.1080/08952841.2015.1017431 
Wilińska, M., \& Cedersund, E. (2010). "Brutal economy"? - Old age and older people in the Polish media. Journal of Aging Studies, 24(4), 335-343.

Wilińska, M., \& Henning, C. (2011). Old age identity in social welfare practices. Qualitative Social Work, 10(3), 346-363. https://doi.org/10.1177/1473325011409477

Wilkinson, J. A., \& Ferraro, K. F. (2002). Thirty years of ageism research. In T. D. Nelson (Ed.), Ageism: Stereotyping and prejudice against older persons (pp. 339-358). Cambridge, MA: MIT Press.

Young-Bruehl, E. (2012). Childism. Confronting prejudice against children. New Haven/London: Yale University Press.

Yuval-Davis, N. (2006). Intersectionality and feminist politics. European Journal of Women's Studies, 13(3), 193-209. https://doi.org/10.1177/1350506806065752

Zajicek, A. M., Calasanti, T. M., \& Zajicek, E. K. (2007). Pension reforms and old people in Poland: An age, class and gender lens. Journal of Aging Studies, 21(1), 55-68. https://doi. org/10.1016/j.jaging.2006.03.002

Open Access This chapter is licensed under the terms of the Creative Commons Attribution 4.0 International License (http://creativecommons.org/licenses/by/4.0/), which permits use, sharing, adaptation, distribution and reproduction in any medium or format, as long as you give appropriate credit to the original author(s) and the source, provide a link to the Creative Commons license and indicate if changes were made.

The images or other third party material in this chapter are included in the chapter's Creative Commons license, unless indicated otherwise in a credit line to the material. If material is not included in the chapter's Creative Commons license and your intended use is not permitted by statutory regulation or exceeds the permitted use, you will need to obtain permission directly from the copyright holder. 